\title{
Entrepreneurship in China and Russia Compared ${ }^{* * *}$
}

\author{
Simeon Djankov, World Bank \\ Yingyi Qian, UC Berkeley \\ Gérard Roland, UC Berkeley \\ Ekaterina Zhuravskaya, CEFIR
}

\begin{abstract}
We compare results from a pilot study on entrepreneurship in China and Russia. Compared to non-entrepreneurs, Russian and Chinese entrepreneurs have more entrepreneurs in their family and among childhood friends, value work more relative to leisure and have higher wealth ambitions. Russian entrepreneurs have a better educational background and their parents were more likely to have been members of the communist party but Chinese entrepreneurs are more risk-taking and greedy and have more entrepreneurs among their childhood friends.
\end{abstract}

Forthcoming in the JEEA 2006 Papers and Proceedings

\footnotetext{
* Acknowledgements: We thank Irina Levina and Xiaolu Wang for excellent research assistance, and the International Finance Corporation for financial support.

**EEail addresses: sdjankov@worldbank.org, yqian@econ.Berkeley.EDU, groland@econ.berkeley.edu, EZhuravskaya@cefir.ru
} 


\section{Introduction.}

The recent development and transition literatures have emphasized the importance of a strong and healthy small and medium enterprise sector for economic growth and development. Endogenous growth theory (Aghion and Howitt, 1997) has emphasized the Schumpeterian approach to growth which advances that entrepreneurial dynamism is fundamental for innovation and growth.

We have launched a research project trying to understand better the determinants of entrepreneurship using surveys of individuals that are being conducted in five large developing and transition countries: Russia, Brazil, China, India, and Nigeria. The samples include both entrepreneurs and non-entrepreneurs in order to understand how these groups differ in terms of three broad sets of variables put forward in social sciences as factors that potentially affect entrepreneurship: 1) individual characteristics such as skills, education, intellectual and personality traits, 2) sociological variables such as family background, social origins, social networks, values and beliefs, and 3) perceptions of the institutional, social and economic environment businesses face. While recent economic research has very much emphasized the role of credit institutions (Banerjee and Newman, 1993) or of institutions securing property rights (Johnson et al., 2002; Besley, 1995; Che and Qian, 1998, Djankov et al., 2002, Frye and Zhuravskaya, 2000, Roland and Verdier, 2003), we want to take a more comprehensive approach and try to disentangle the role all these factors play in promoting entrepreneurship across a variety of settings.

This paper reports and compares some findings from a pilot survey conducted in Russia in 2003-2004 and in China in 2004-2005.

\section{The data.}

In both Russia and China, we surveyed individuals in seven large cities in four different regions. To capture some of the regional heterogeneity in these countries, the regions were selected to maximize the cross-regions variation in the business climate. In Russia, the survey was done in Moscow; in Nizhny Novgorod and Dzershinsk in the Nizhegorodskaya Oblast: in Perm and Chaykovsky in the Permskaya Oblast; and in Rostov on the Don and Taganrog in the Rostovskaya Oblast. In China, the survey was conducted in Beijing; in Wuhan and Huangshi in Hubei Province; in Guangzhou and Zhongshan in Guangdong Province; and in Xi'An and Baoji in Shaanxi Province.

In each country, we first surveyed a random sample of about 400 entrepreneurs (100 in Moscow and Beijing metropolitan areas and 50 in each of the other six cities). These surveys were conducted in the fall of 2003 in Russia and in the fall of 2004 in China. We define entrepreneur as an owner-manager of a business with five or more employees because we wanted to make sure that individuals who we call entrepreneurs in our sample are more than just self-employed. After completion of the surveys of entrepreneurs in the respective countries, we conducted a survey of about 550 non-entrepreneurs in the same cities using a similar instrument. ${ }^{1}$ We defined non-entrepreneurs as individuals who are not working for their own business. Non-entrepreneur surveys took place during the spring of 2004 and 2005 in Russia and China, respectively. In both countries $80 \%$ of respondents in the non-

\footnotetext{
${ }^{1} 400$ entrepreneurs and 550 non entrepreneurs was the target sample size given to the survey firms in both countries. In reality, these firms interviewed a slightly larger number of individuals to make sure that in the end we have the targeted number of valid questionnaires. The actual number of observations in the empirical analysis depends on the response rates for each particular question,.
} 
entrepreneur sample were chosen randomly conditional on matching the age, gender and educational attainment of entrepreneurs from the respective entrepreneur surveys and $20 \%$ were chosen at random. Finally, in each country a short survey was run among a random sample of 1,200 individuals (with the same breakdown across cities) asking nine questions about their personal characteristics, including a question about whether or not they are an entrepreneur or self-employed to get data on prevalence of entrepreneurship across cities. In all of the empirical analysis, the observations are weighted with weights equal to the inverse of the probability for a particular respondent (entrepreneur or non-entrepreneur) to get into our sample. The weights reflect differences in entrepreneurship, age, gender, and education across cities in the population, as well as the city size.

\section{Comparing entrepreneurs to non-entrepreneurs in China and Russia.}

In this section, we summarize differences in individual characteristics, social environment, values, beliefs, and perceptions of institutional environment for entrepreneurs and non-entrepreneurs in both countries. We report means for entrepreneurs and nonentrepreneurs in both countries on various questions from the survey. In order to have comparability, the means are conditional on gender, age, and education (with a quadratic term) of respondents and on city dummies. The standard errors and p-values for the differences in means between entrepreneurs and non-entrepreneurs are adjusted to allow for clustering of the error terms at the level of cities.

INSERT TABLE 1

First, we summarize differences in individual characteristics of entrepreneurs and non-entrepreneurs. Entrepreneurs on average are more mobile across jobs and geographically. In Russia, entrepreneurs have lived in significantly more localities than non-entrepreneurs and have had a significantly higher number of distinct professional activities. Although these differences have the same sign in China, they are statistically insignificant. In China, however, entrepreneurs worked in a significantly higher number of industries compared to non-entrepreneurs. This is in line with recent findings of Lazear (2002) who surveyed the population of former Stanford MBA students and found that those with a higher number of jobs and shorter job tenures before business school were most likely to become entrepreneurs afterwards.

In line with a common perception that entrepreneurship is associated with risk-taking, entrepreneurs report significantly lower risk aversion than non-entrepreneurs. When asked whether respondents were willing to accept one of two risk-neutral gambles -1 ) win $\$ 10$ with probability $1 / 2$ and lose $\$ 10$ with probability $1 / 2$ or 2 ) win $\$ 20$ with probability $1 / 2$ and lose $\$ 20$ with probability $1 / 2-77 \%$ of entrepreneurs in Russia and $90 \%$ of entrepreneurs in China responded yes (compared to $67 \%$ and $57 \%$ of non-entrepreneurs in Russia and China, respectively).

Entrepreneurs report higher levels of satisfaction with life compared to nonentrepreneurs. First, in Russia, a significantly higher share of entrepreneurs (92\%) answered yes to the question whether they are happy compared to $73 \%$ of non-entrepreneurs. In China, this difference has the same sign but is insignificant. Second, entrepreneurs report to be in significantly better health than non-entrepreneurs in both countries. Finally, entrepreneurs are taller than non-entrepreneurs. The difference in height is statistically significant only in China. In addition, entrepreneurs marry more often and have more kids. The difference in \% of married is significant in Russia and insignificant in China; while the difference in the number of children is significant in China only. 
There are important differences between the two countries in religiosity and school achievement of entrepreneurs compared to non-entrepreneurs. Russian entrepreneurs tend to be less religious but Chinese entrepreneurs are more religious. However, religiosity is very low in China (12\% among entrepreneurs) and relatively high in Russia (68\%).

Russian entrepreneurs report to have been higher achievers in school but this is not the case for China. Entrepreneurs tend to speak less foreign languages, an interesting fact. They scored higher than non-entrepreneurs on a test of cognitive ability, focusing on shortterm recall (a digit-span test, available from the authors upon request) but the difference is not significant.

Another important difference that emerges relates to leisure-work choices of entrepreneurs and non-entrepreneurs. Respondents were asked whether they would retire if they received a windfall income of 100 or 500 times (5,000 times also in China) the annual GDP per capita of the country. Entrepreneurs were much less likely to respond positively than non-entrepreneurs. In both countries, a very strong reason for not retiring was the desire to earn more money. In Russia, job satisfaction and a feeling of being socially useful played a significant role also but not in China where one finds the opposite.

Now let us focus on social environment. Compared to non-entrepreneurs, a larger share of parents of Russian entrepreneurs (73\% vs $48 \%$ ) achieved higher or special education. There are no differences in parents' education in China. Nevertheless, fathers of entrepreneurs in both countries were more likely to have been bosses or directors (19\% vs. $12 \%$ in Russia and 30\% vs. $13 \%$ in China). In Russia, both parents of entrepreneurs were more likely to have been members of the communist party but not in China. Not only is there no significant difference for fathers in China but mothers of entrepreneurs were less often members of the communist party (10\% compared to $15 \%$ for non-entrepreneurs).

A very large difference that emerges in both countries is the proportion of entrepreneurs in one's family and among one's friends. Entrepreneurs in both countries are much more likely to have entrepreneurs in their family (57\% in Russia and $49 \%$ in China compared to respectively $34 \%$ and $24 \%$ among non-entrepreneurs). Respondents were asked to name five friends from their childhood and adolescence, and then to report how many of these five have become entrepreneurs. The difference in response for entrepreneurs and nonentrepreneurs is striking. In China, for example, $60 \%$ of entrepreneurs had adolescent friends who became entrepreneurs compared to $24 \%$ among non-entrepreneurs.

We also asked questions about values and beliefs. While there are statistically significant differences between entrepreneurs and non-entrepreneurs, the magnitude of the differences is not very large except for a few cases. A major difference is the value attached to work: $75 \%$ of Russian and $80 \%$ of Chinese entrepreneurs consider work to be very important in their life compared to 53\% and 63\% for non-entrepreneurs in Russia and China. This is consistent with the labor-leisure preferences reported above. Note that Chinese entrepreneurs value political freedom very strongly compared to non-entrepreneurs (73\% against 28\%) whereas Russian entrepreneurs value political freedom significantly less than non-entrepreneurs (62\% against 74\%) even though they value it highly. Entrepreneurs seem to value relations with parents significantly less than non-entrepreneurs in both countries. Asked about social norms, entrepreneurs in both countries consider that bribes are more acceptable. This probably reflects their greater experience in the business environment rather than intrinsic values. Chinese entrepreneurs consider that shirking at work can be justified. We asked many questions about trust but no strong pattern emerged. Russian entrepreneurs are considerably less trustful of foreigners and of people out of town whereas there is no significant difference in China. It is worth noting that Russians (both entrepreneurs and non- 
entrepreneurs) trust the government at all levels substantially less than Chinese (for example, $37 \%$ of respondents had at least some trust in the central government in Russia compared to $77 \%$ in China).

Finally, we compare individual perceptions of entrepreneurs and non-entrepreneurs about the institutional environment controlling for the average differences across cities. Chinese entrepreneurs find that local government is more favorable to entrepreneurs (82\% positive answers against $70 \%$ for non-entrepreneurs). In Russia, entrepreneurs find that local government is less favorable (only $49 \%$ of positive answers) even though the difference is not significant. In general, the perception of different levels of government regarding their attitude to entrepreneurs is more negative among Russian entrepreneurs compared to nonentrepreneurs. In China, it is only more negative with respect to the central government and even there the percentage of positive answers is higher than in Russia. Entrepreneurs in China also feel more secure with respect to theft of property. Russian entrepreneurs tend to distrust the courts more than non-entrepreneurs. In China, it is the opposite. When asked if they would go to court if abused by a government official, roughly $72 \%$ say yes in both countries. However, only $62 \%$ of Russian entrepreneurs respond positively whereas $80 \%$ of Chinese entrepreneurs do.

To summarize the main results of this section, entrepreneurs in both countries are risk-taking and have more entrepreneurs in their families and among their childhood and adolescence friends. Entrepreneurs value work very highly and are greedy. Russian entrepreneurs tend to come from a higher educational background but have a more negative perception of the institutional environment in which they operate compared to Chinese entrepreneurs. The latter tend to have a positive view of local governments' attitude towards entrepreneurs.

\section{Results of multivariate probit regressions}

In this section, we report results of multivariate analysis. We explain variation in individual decisions to become an entrepreneur in probit regressions with independent variables that can plausibly be considered exogenous to this decision. The main objective of these regressions is to see which variables are robustly associated to entrepreneurship and also to compare the differences between Russia only and China only.

INSERT TABLE 2.

The results are reported in table 2. Column 1 in Table 2 reports pooled results, columns 2 and 3 report separate results for Russia only and China only and columns 4 and 5 present a regression where all dependent variables include interactions with China dummy. The fourth column should thus be read as result for Russia ${ }^{2}$ and the coefficients in the fifth column represent the difference in China relative to Russia. As above, all regressions include city fixed effects and controls for gender, age and a quadratic function of education. Standard errors are adjusted for clusters in error terms at the city level.

The pooled results in Table 1 show that entrepreneurship is positively associated with the father having been a member of the communist party, the mother having been a boss or a director, having family and friends being entrepreneurs (social network), greed (not willing to retire to earn more money) and a positive perception of the attitude of the local population towards entrepreneurs. However, when looking at the country regressions, one sees that only the social network variables and greed are robustly significant in both countries. Note from

\footnotetext{
${ }^{2}$ The results of column 2 and 4 are identical when the data are not weighted but they are slightly different because the weights are different in a regression including one versus countries.
} 
columns 2 and 3 that height has a negative coefficient in Russia and a positive one in China. Columns 2 and 4 show that for Russia having had a father in the communist party and a mother director has positive correlation with entrepreneurship as well as for reporting to have been among the top $10 \%$ in school and also a positive perception of the population's attitude towards entrepreneurs. Column 5 shows the significant differences between entrepreneurship in China and Russia. Chinese entrepreneurs are more greedy and risk-taking (the Russia coefficient is negative but this is not the case in other specifications), are more likely to have entrepreneurs among their former school friends and were less good in school.

In terms of the importance of the different effects, since the reported coefficients are marginal effects, looking at column 1, the two most important effects are greed and having friends entrepreneurs. A one standard deviation increase in greed, increases the probability of being an entrepreneurs by about $9 \%$ while a one standard deviation increase in the "friends entrepreneurs" variable increases this probability by $7.2 \%$.

As with most cross-section OLS regressions, we cannot rule out the possibility that an omitted variable simultaneously influenced entrepreneurship decisions of our respondents and of their families and friends. Thus, at this stage, we cannot establish a causal link between social networks and entrepreneurship; but we hope to address the question of causality in the subsequent stages of this project.

\section{INSERT TABLE 3}

So far we have held the variation in city-level institutional environment constant by including city dummies. To evaluate the effect of city-level institutional environment, we regress a dummy that equals one if entrepreneur plans to expand sales or employment on the average city-level measures of corruption and efficiency of courts (as reported in Table 1). These regressions include controls (not shown) for industry dummies and all individual characteristics as reported in Table 2. As above, error terms are clustered at the city-level. As one can see, these institutional variables are significant and have the expected sign. Note also the country effect showing the stronger economic dynamism in China.

\section{Conclusions.}

Russian and Chinese entrepreneurs have common characteristics relative to nonentrepreneurs controlling for age, gender and education. They are more risk-taking, place a higher value on work relative to leisure, are greedy and are much more likely to have entrepreneurs in their family as well as among childhood and adolescence friends. There are however also differences. Russian entrepreneurs have a better educational background which is not the case for Chinese entrepreneurs and are more risk-taking and greedy and are even more likely than in Russia to have had school friends who became entrepreneurs. In future work, we want to understand better in particular the role of social networks and the channels through which they operate for entrepreneurs.

\section{REFERENCES}

Aghion, Philippe and Peter Howitt (1997). Endogenous Growth Theory, MIT Press, Cambridge Massachussetts.

Banerjee, Abhijit and Andrew Newman (1993). “Occupational Choice and the Process of Development” Journal of Political Economy, 101(2).

Besley, Tim (1995). "Property Rights and Investment Incentives: Theory and Evidence from Ghana," Journal of Political Economy, Vol. 103 (5) pp. 903-37 
Che, Jiahua and Yingyi Qian (1998). "Insecure Property Rights and Government Ownership of Firms,” Quarterly Journal of Economics, May, 113(2), pp. 467496.

Djankov, Simeon, Ed Glaeser, Andrei Shleifer (2002). "The Regulation of Entry” Quarterly Journal of Economics, 1-37.

Djankov. S. E. Miguel, Y. Qian, G. Roland and E. Zhuravskaya (2005) "Who are

Russia's Entrepreneurs ?” Journal of the European Economic Association, Vol. 3 (2-3), April-May, pp. 587-597.

Frye, Timothy and Ekaterina Zhuravskaya (2000). "Rackets, Regulation and the Rule of Law," Journal of Law, Economics, and Organization, Vol. 16 (2) pp. 478502.

Johnson, Simon, John McMillan and Chris Woodruff, (2002). "Property Rights and Finance," American Economic Review, 92 (5) pp. 1335-1356.

Lazear, E. (2002). "Entrepreneurship," NBER Working Paper No. w9109.

Roland, Gérard and Thierry Verdier (2003). "Law Enforcement and Transition”, European Economic Review.. 
TABLE 1. Entrepreneurs in Russia and China (comparison of means).

\begin{tabular}{|c|c|c|c|c|c|c|c|c|}
\hline \multirow{2}{*}{ Individual Characteristics: } & \multicolumn{4}{|c|}{ Russia } & \multicolumn{4}{|c|}{ China } \\
\hline & $\begin{array}{c}\text { Entre- } \\
\text { preneurs }\end{array}$ & $\begin{array}{c}\text { Non } \\
\text { Entre- } \\
\text { preneurs }\end{array}$ & \multicolumn{2}{|c|}{$\begin{array}{l}\text { p-value } \\
\text { for test } \\
\text { of } \\
\text { difference } \\
\text { in means }\end{array}$} & $\begin{array}{c}\text { Entre- } \\
\text { preneurs }\end{array}$ & $\begin{array}{c}\text { Non } \\
\text { Entre- } \\
\text { preneurs }\end{array}$ & \multicolumn{2}{|c|}{$\begin{array}{c}\text { p-value } \\
\text { for test } \\
\text { of } \\
\text { difference } \\
\text { in means }\end{array}$} \\
\hline Number of localities lived & 2.42 & 2.18 & 0.01 & $* * *$ & 1.85 & 1.55 & 0.15 & \\
\hline Number of distinct professional activities & 2.76 & 2.54 & 0.06 & * & 2.40 & 2.13 & 0.24 & \\
\hline Number of industries respondent worked in & & & & & 1.85 & 1.58 & 0.00 & $* * *$ \\
\hline Accept a risk neutral gamble, \% & 0.77 & 0.67 & 0.00 & $* * *$ & 0.90 & 0.57 & 0.01 & $* * *$ \\
\hline Very happy or quite happy in life, \% & 0.92 & 0.73 & 0.00 & $* * *$ & 0.92 & 0.91 & 0.76 & \\
\hline Very successful or quite successful in life, \% & 0.74 & 0.37 & 0.00 & $* * *$ & 0.64 & 0.43 & 0.01 & $* * *$ \\
\hline Good health, self described, \% & 0.12 & 0.07 & 0.00 & $* * *$ & 0.51 & 0.37 & 0.09 & * \\
\hline Got ill last week, \% & 0.25 & 0.30 & 0.02 & $* *$ & 0.04 & 0.08 & 0.00 & $* * *$ \\
\hline Height, cm & 172.58 & 172.38 & 0.43 & & 169.04 & 168.22 & 0.02 & $* * *$ \\
\hline Married, \% & 0.74 & 0.60 & 0.00 & $* * *$ & 0.84 & 0.80 & 0.53 & \\
\hline Number of children & 1.34 & 1.31 & 0.22 & & 1.19 & 0.99 & 0.00 & $* * *$ \\
\hline Religious believer, \% & 0.68 & 0.78 & 0.00 & $* * *$ & 0.12 & 0.08 & 0.09 & $*$ \\
\hline Cognitive text score & 3.32 & 3.15 & 0.15 & & 3.92 & 3.80 & 0.62 & \\
\hline Top 10\% in secondary school (self reported), \% & 0.44 & 0.34 & 0.00 & $* * *$ & 0.37 & 0.38 & 0.82 & \\
\hline $\begin{array}{l}\text { Top } 10 \% \text { in high school, } \\
\text { college or university (self reported), \% }\end{array}$ & 0.41 & 0.38 & 0.13 & & 0.36 & 0.38 & 0.10 & \\
\hline Speak foreign language, \% & 0.38 & 0.58 & 0.01 & $* *$ & 0.35 & 0.49 & 0.22 & \\
\hline \multicolumn{9}{|l|}{ Motivation, Greed: } \\
\hline Retire if won 100 times GDP per capita, \% & 0.08 & 0.27 & 0.00 & $* * *$ & 0.05 & 0.24 & 0.02 & $* *$ \\
\hline Retire if won 500 times GDP per capita, \% & 0.18 & 0.29 & 0.00 & $* * *$ & 0.14 & 0.37 & 0.00 & $* * *$ \\
\hline Retire if won 5000 times GDP per capita, \% & $\cdot$ & . & . & & 0.31 & 0.44 & 0.05 & $*$ \\
\hline Not retire if won a large sum: I like what I do, \% & 0.82 & 0.69 & 0.00 & $* * *$ & 0.74 & 0.75 & 0.93 & \\
\hline Not retire if won a large sum: I want more money, \% & 0.50 & 0.28 & 0.00 & $* * *$ & 0.70 & 0.43 & 0.01 & $* * *$ \\
\hline $\begin{array}{l}\text { Not retire if won a large sum: my work serves } \\
\text { useful social purpose, \% }\end{array}$ & 0.70 & 0.37 & 0.00 & $* * *$ & 0.18 & 0.81 & 0.00 & $* * *$ \\
\hline \multicolumn{9}{|l|}{ Sociological Characteristics: } \\
\hline Father has secondary special or higher education, \% & 0.73 & 0.48 & 0.00 & $* * *$ & 0.29 & 0.27 & 0.57 & \\
\hline Mother has secondary special or higher education, \% & 0.73 & 0.48 & 0.00 & $* * *$ & 0.14 & 0.18 & 0.46 & \\
\hline Father was a boss or director, $\%$ & 0.19 & 0.12 & 0.00 & $* * *$ & 0.30 & 0.13 & 0.02 & $* *$ \\
\hline Mother was a boss or director, \% & 0.08 & 0.00 & 0.00 & $* * *$ & 0.06 & 0.03 & 0.10 & \\
\hline $\begin{array}{l}\text { Father was a worker or employee } \\
\text { without special education, \% }\end{array}$ & 0.43 & 0.44 & 0.43 & & 0.56 & 0.72 & 0.01 & $* *$ \\
\hline $\begin{array}{l}\text { Mother was a worker or employee } \\
\text { without special education, \% }\end{array}$ & 0.30 & 0.53 & 0.00 & $* * *$ & 0.70 & 0.71 & 0.86 & \\
\hline Father was a member of the Communist party, \% & 0.48 & 0.37 & 0.00 & $* * *$ & 0.40 & 0.31 & 0.42 & \\
\hline Mother was a member of the Communist party, \% & 0.19 & 0.12 & 0.01 & $* * *$ & 0.10 & 0.15 & 0.01 & $* * *$ \\
\hline Members of the family were running business, $\%$ & 0.57 & 0.34 & 0.00 & $* * *$ & 0.49 & 0.24 & 0.00 & $* * *$ \\
\hline $\begin{array}{l}\text { Had childhood friends, who } \\
\text { became entrepreneurs, \% }\end{array}$ & 0.59 & 0.37 & 0.00 & $* * *$ & 0.45 & 0.28 & 0.01 & $* *$ \\
\hline $\begin{array}{l}\text { Had adolescent friends, who } \\
\text { became entrepreneurs, \% }\end{array}$ & 0.67 & 0.48 & 0.00 & $* * *$ & 0.60 & 0.24 & 0.00 & $* * *$ \\
\hline Values: & & & & & & & & \\
\hline
\end{tabular}


Friends are very important, \%

Relations with parents are very important, \%

Financial well-being is very important, $\%$

Leisure time is very important, \%

Health is very important, \%

Service to others is very important, \%

Political freedom is very important, \%

Power is very important, \%

Work is very important, \%

Intellectual achievement is very important, \%

Values of Legal Social Norms:

Not paying a fare can be justified to some degree, \% Shirking at work can be justified to some degree, \%

Accepting a bribe can be justified to some degree, \%

\section{Trust:}

Most people can be trusted, \%

Have a lot of trust in family members, \%

Have a lot of trust in friends, \%

Have a lot of trust in colleagues, \%

Have a lot of trust or some trust in businessmen, \%

Have a lot of trust or some trust in subordinates, \%

Have a lot of trust or some trust

in other people from town, $\%$

Have a lot of trust or some trust in foreigners, \%

Have a lot of trust or some trust

in local government officials, \%

Have a lot of trust or some trust in

regional government officials, \%

Have a lot of trust or some trust in

central government officials, \%

\section{Individual Perceptions of Institutions:}

People in your town are

favorable towards entrepreneurs, \%

Local government is

Favorable towards entrepreneurs, \%

Regional government is

favorable towards entrepreneurs, \%

Central government is

Favorable towards entrepreneurs, \%

Private entrepreneurs pay bribes

to avoid regulations, \%

Private entrepreneurs pay bribes to change rules, \%

Are businessmen subject to theft of property, \%

Go to court against a business relation if cheated, \%

Go to court against a government official

if abused, \%

It is relatively easy to find money

to start a business in town, $\%$

\begin{tabular}{|c|c|c|c|c|c|c|c|}
\hline 0.43 & 0.53 & 0.01 & $* * *$ & 0.60 & 0.66 & 0.16 & \\
\hline 0.84 & 0.92 & 0.00 & $* * *$ & 0.86 & 0.88 & 0.10 & $*$ \\
\hline 0.53 & 0.58 & 0.02 & $* *$ & 0.73 & 0.62 & 0.08 & $*$ \\
\hline 0.23 & 0.26 & 0.02 & $* *$ & 0.19 & 0.20 & 0.85 & \\
\hline 0.75 & 0.80 & 0.00 & $* * *$ & 0.93 & 0.88 & 0.20 & \\
\hline 0.21 & 0.29 & 0.00 & $* * *$ & 0.19 & 0.19 & 0.92 & \\
\hline 0.62 & 0.74 & 0.03 & $* *$ & 0.73 & 0.28 & 0.00 & $* * *$ \\
\hline 0.10 & 0.07 & 0.00 & $* * *$ & 0.32 & 0.26 & 0.01 & $* *$ \\
\hline 0.75 & 0.53 & 0.00 & $* * *$ & 0.80 & 0.63 & 0.00 & $* * *$ \\
\hline 0.43 & 0.49 & 0.00 & $* * *$ & 0.24 & 0.33 & 0.02 & $* *$ \\
\hline 0.77 & 0.76 & 0.68 & & 0.08 & 0.05 & 0.48 & \\
\hline 0.54 & 0.58 & 0.27 & & 0.23 & 0.07 & 0.00 & $* * *$ \\
\hline 0.32 & 0.18 & 0.00 & $* * *$ & 0.19 & 0.06 & 0.00 & $* * *$ \\
\hline 0.16 & 0.22 & 0.05 & $* *$ & 0.56 & 0.54 & 0.79 & \\
\hline 0.90 & 0.86 & 0.00 & $* * *$ & 0.96 & 0.92 & 0.48 & \\
\hline 0.49 & 0.48 & 0.17 & & 0.58 & 0.58 & 0.98 & \\
\hline 0.26 & 0.20 & 0.02 & $* *$ & 0.38 & 0.33 & 0.46 & \\
\hline 0.61 & 0.66 & 0.06 & $*$ & 0.71 & 0.46 & 0.02 & $* *$ \\
\hline 0.79 & 0.82 & 0.06 & $*$ & 0.95 & 0.83 & 0.02 & $* *$ \\
\hline 0.54 & 0.85 & 0.00 & $* * *$ & 0.42 & 0.50 & 0.29 & \\
\hline 0.44 & 0.70 & 0.00 & $* * *$ & 0.29 & 0.38 & 0.39 & \\
\hline 0.40 & 0.40 & 1.00 & & 0.69 & 0.59 & 0.07 & * \\
\hline 0.39 & 0.42 & 0.38 & & 0.68 & 0.64 & 0.43 & \\
\hline 0.40 & 0.41 & 0.76 & & 0.75 & 0.75 & 0.99 & \\
\hline 0.67 & 0.65 & 0.36 & & 0.68 & 0.60 & 0.33 & \\
\hline 0.49 & 0.53 & 0.26 & & 0.82 & 0.70 & 0.00 & $* * *$ \\
\hline 0.51 & 0.61 & 0.01 & $* * *$ & 0.78 & 0.76 & 0.74 & \\
\hline 0.57 & 0.62 & 0.08 & * & 0.81 & 0.90 & 0.10 & * \\
\hline 0.72 & 0.83 & 0.00 & $* * *$ & 0.50 & 0.54 & 0.57 & \\
\hline 0.56 & 0.69 & 0.00 & $* * *$ & 0.40 & 0.50 & 0.39 & \\
\hline 0.88 & 0.85 & 0.18 & & 0.70 & 0.98 & 0.08 & * \\
\hline 0.66 & 0.71 & 0.01 & $* *$ & 0.90 & 0.88 & 0.48 & \\
\hline 0.62 & 0.72 & 0.00 & $* * *$ & 0.80 & 0.73 & 0.00 & $* * *$ \\
\hline 0.21 & 0.16 & 0.02 & $* *$ & 0.38 & 0.26 & 0.28 & \\
\hline
\end{tabular}

Note: The reported differences in means are conditional on city-level variation, age, gender, education, and education squared. Standard errors (and P-values) are adjusted to allow clusters of error term at the level of cities. 
Table 2. Entrepreneurship in Russia and China. Probit regressions. Marginal effects reported.

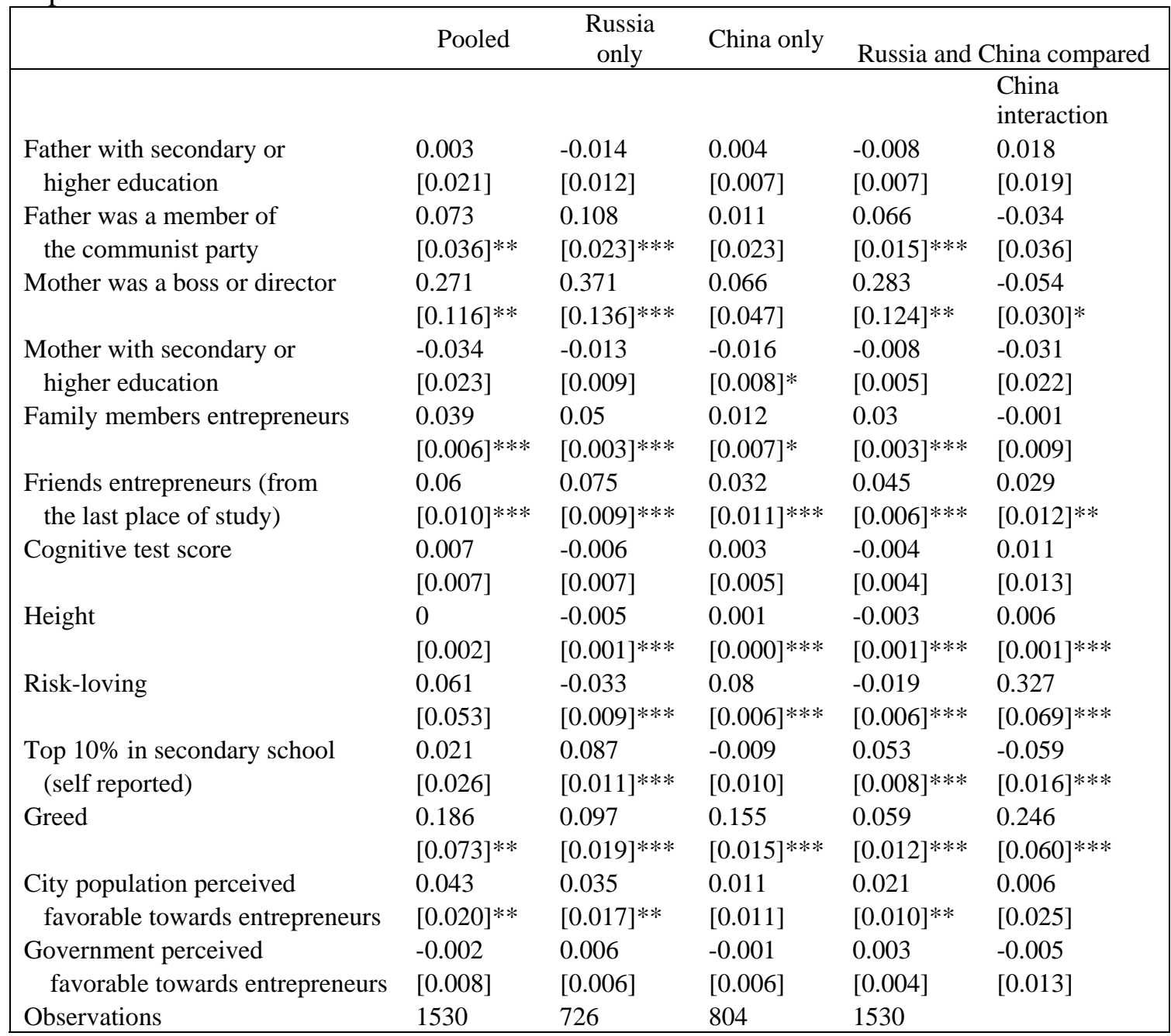

Robust standard errors corrected for clusters of error term at city level in brackets. Also control for gender, age, education, and education squared. * significant at $10 \%$; ** significant at $5 \%$; *** significant at $1 \%$

Table 3. Institutions and plans to expand sales and employment. Entrepreneur sample.

\begin{tabular}{|lllll|}
\hline & $\begin{array}{l}\text { Planned } \\
\text { sales } \\
\text { growth } \\
\text { average city-level corruption }\end{array}$ & $\begin{array}{l}\text { Planned } \\
\text { employment } \\
\text { growth } \\
\text { average city-level efficiency of courts }\end{array}$ & $\begin{array}{l}\text { Planned } \\
\text { sales } \\
\text { growth }\end{array}$ & $\begin{array}{l}\text { Planned } \\
\text { employment } \\
\text { growth }\end{array}$ \\
Country & & & & \\
& -1.503 & & \\
{$[0.608]^{* *}$} & {$[0.751]^{*}$} & 1.215 & 1.047 \\
Observations & 0.364 & 0.026 & 0.294 & -0.035 \\
& {$[0.091]^{* * *}$} & {$[0.268]$} & {$[0.136]^{*}$} & {$[0.326]$} \\
\hline
\end{tabular}

Robust standard errors corrected for clusters of error term at city level in brackets. Also control for gender, age, education, and education squared. * significant at $10 \%$; ** significant at $5 \%$; *** significant at $1 \%$. All regressions include industry dummies and all the regressors as in the first column of table 2 . 